\title{
The Application of the Two Stay Two Stray Learning Model and Co-Op Co-Op for the Improvement of Students' Learning Outcome in the Environmental Epidemiology Subject
}

\author{
Taufiq Ihsan ${ }^{1 *}$ Tivany Edwin ${ }^{1}$ \\ ${ }^{1}$ Environmental Engineering Department, Faculty of Engineering Universitas Andalas, Padang 25163 INDONESIA \\ *Corresponding author.Email: taufiqihsan@eng.unand.ac.id
}

\begin{abstract}
This study aimed to determine the improvement of the Environmental Epidemiology Subject's learning outcomes through Two Stay Two Stray (TSTS) and Co-op Co-op learning model strategy. This study was a classroom action research and compared the scores in the semester of the academic year 2018/2019 (conventional class) and 2019/2020 (learning model strategy). This study's subjects were 45 fourth grade students. The average midtest score obtained by students was increasing with 72.07. From the results of the t-test, it is obtained that the t-count at 2.94 is higher than the t-table of 2.026. This data showed that the learning outcomes of students increased significantly compared to conventional. Based on these results, it can be concluded that the TSTS and Co-op Co-op that was the model that invites the students to be active through the group in the learning activities.
\end{abstract}

Keywords: Two Stay Two Stray, Co-op Co-op, Learning Outcome, Environmental Epidemiology Subject

\section{INTRODUCTION}

Cooperation of understudies in learning exercises was significant, so understudies can comprehend the material showed better, interface with regular day to day existence, and associate with the earth. The proper learning model to build up understudies' capacity to connect with their condition was helpful. As per Suprijono [1] cooperative learning model can improve students' learning outcomes, increase tolerance, mutual respect for differences, and develop social skills. Two of the collaborative learning models that can be utilized to improve learning results and ready to inspire understudies in learning exercises are Two Stay Two Stray (TSTS) and Co-op Co-op learning model. The two models welcome understudies to concentrate on gatherings, and each meeting comprises of four individuals.

This study aimed to research the cooperative learning model of TSTS and Co-op Co-op implemented in the environmental epidemiology subject at the Environmental Engineering Department of Universitas Andalas Indonesia to create an active and fun learning situation that will improve the outcome. The learning model applied to the Environmental Epidemiology subject was conventional or known as the Teacher Center Content Learning. The final score of students obtained in the previous semester was
$6.22 \%$, failing in this subject. The dominant score is B grade. As the main course for fourth-degree students, it means that the material in this course is fundamental, and students should have the ability more to get the best score in this course.

TSTS learning model was one of the types of cooperative learning that gives groups the chance to distribute the outcome and information to other groups. According to Sulisworo \& Suryani [2], by using the TSTS structure, students will get used to respecting others opinions. They can express their views to others and increase their confidence in expressing ideas. Co-op co-op was developed by Robert E. Slavin [3], who stated that coop co-op was a familiar type of group investigation. This method places teams in cooperation between one another to learn a topic in class. This method pushes the students to be active and cooperative in mastering the material. The Co-op Co-op model gives students chances to work in small groups by learning and finishing some tasks to increase their comprehension. Then it provides opportunities for the students to share their new knowledge with their friends. According to Kagan \& Kagan [4], using co-op co-op can increase students' comprehension about themselves and the world, and it can give them chances to share their new viewpoint to others. 
This model's goal is for the students to be cooperative in finding a concept, and its usage can lead them to be active in discussion, Q\&A, finding answers, and explaining the materials. Based on those explanations, the researchers intend to conduct a classroom action research with these models [5].

\section{METHODOLOGY}

The type of this research is Classroom Action Research (CAR). The researcher acts as a planner, implementer of action, observer, reflector, and reporter of research results to improve the learning process. This research was done at the Environmental Engineering Department, Faculty of Engineering Universitas Andalas, Indonesia. This research subject was even

semester 2019/2020 academic year comprising of 45 students, 11 males, and 34 females. The collected data in this CAR is the data regarding the cognitive learning outcome using those models in the Environmental Epidemiology subject using those learning models.

Data analysis was started from the beginning until the end of the research. Then the data was processed and reported. The data in the forms of sentences or words are analyzed and concluded. The steps in data analysis are data reduction, presentation, and conclusion. Every cycle consists of planning, implementing, observing, and reflecting. In the second cycle, every step is the same as the first one, but it is done for the second one to decrease the deficiency of the first cycle [6,7]. The learning model syntax for TSTS and Co-op Co-op is as follows in Table 1.

Table 1. Learning Model Syntax TSTS dan Co-op Coop Learning Models

\begin{tabular}{|c|c|c|}
\hline TSTS & Сo-Оp-Сo-Оp & $\begin{array}{c}\text { TSTS and } \\
\text { Co-op-Co-op }\end{array}$ \\
\hline $\begin{array}{l}\text { 1. Students work } \\
\text { together in groups } \\
\text { of } 4 .\end{array}$ & $\begin{array}{l}\text { 1. Selecting the } \\
\text { learning group of } \\
\text { students and form the } \\
\text { groups. }\end{array}$ & $\begin{array}{l}\text { 1. Students } \\
\text { cooperate in groups } \\
\text { of } 4 \text {. }\end{array}$ \\
\hline $\begin{array}{l}\text { 2. The teacher } \\
\text { gives tasks to each } \\
\text { group to discuss } \\
\text { and solve } \\
\text { together. }\end{array}$ & $\begin{array}{l}\text { 2. The teacher lets th } \\
\text { students pick their } \\
\text { topics. }\end{array}$ & $\begin{array}{l}\text { 2. The teacher } \\
\text { distributes the } \\
\text { issues for each } \\
\text { group. }\end{array}$ \\
\hline
\end{tabular}

\begin{tabular}{|c|c|c|}
\hline TSTS & Сo-Op-Co-Op & $\begin{array}{c}\text { TSTS and } \\
\text { Co-op-Co-op }\end{array}$ \\
\hline $\begin{array}{l}\text { 3. When finished, } \\
\text { two people from } \\
\text { each group } \\
\text { become the guests } \\
\text { of the other two } \\
\text { groups. }\end{array}$ & $\begin{array}{l}\text { 3. Each group } \\
\text { distributes the topics } \\
\text { for the task } \\
\text { distribution for each } \\
\text { group member. Group } \\
\text { members are } \\
\text { encouraged to share } \\
\text { references and } \\
\text { learning materials. }\end{array}$ & $\begin{array}{l}\text { 3. Every group } \\
\text { distributes the tasks } \\
\text { to each member. }\end{array}$ \\
\hline $\begin{array}{l}\text { 4. The two people } \\
\text { remaining in the } \\
\text { group has to } \\
\text { distribute the work } \\
\text { result and } \\
\text { information to } \\
\text { their guest. }\end{array}$ & $\begin{array}{l}\text { 4. Small topic } \\
\text { kpresentation in } \\
\text { groups. }\end{array}$ & $\begin{array}{l}\text { 4. The members } \\
\text { present their } \\
\text { achievements in } \\
\text { their group. }\end{array}$ \\
\hline $\begin{array}{l}\text { 5. Guest excuses } \\
\text { themselves and go } \\
\text { back to their } \\
\text { groups and report }\end{array}$ & $\begin{array}{l}\text { 5. Each group } \\
\text { presents the result of } \\
\text { their discussion on the } \\
\text { topics. Every member }\end{array}$ & $\begin{array}{l}\text { 5. Two of the } \\
\text { students from each } \\
\text { group left the group }\end{array}$ \\
\hline $\begin{array}{l}\text { all they have } \\
\text { learned from other } \\
\text { presentation. group }\end{array}$ & $\begin{array}{l}\text { is responsible for the } \\
\text { proup }\end{array}$ & $\begin{array}{l}\text { and be the guest of } \\
\text { other groups. }\end{array}$ \\
\hline $\begin{array}{l}\text { 6. Groups match } \\
\text { and discuss the } \\
\text { result of their } \\
\text { work. }\end{array}$ & & $\begin{array}{l}\text { 6. Two remaining } \\
\text { students share the } \\
\text { result of their } \\
\text { discussion with the } \\
\text { guests. }\end{array}$ \\
\hline 7. Conclusion & & $\begin{array}{l}\text { 7. Guests leave the } \\
\text { groups they visited, } \\
\text { return to their } \\
\text { groups, and report } \\
\text { the findings. }\end{array}$ \\
\hline \multicolumn{3}{|l|}{$\begin{array}{l}\text { 8. Groups match } \\
\text { and discuss the } \\
\text { result of their } \\
\text { discussion. }\end{array}$} \\
\hline $\begin{array}{l}\text { 9. Groups present } \\
\text { their discussion } \\
\text { result. }\end{array}$ & & \\
\hline
\end{tabular}

\section{RESULTS AND DISCUSSION}

The results showed that student activity had increased in the 19/20 even semester that had been carried out. This data can be seen in the acquisition of student midterm exam scores, rising from the even semester $18 / 19$. In the past year, the average midtest 
score obtained by students was 66.18 , while in the present year, it has increased better with an average rating of 72.07. The comparison of students' midtest scores can be seen in the following graph.

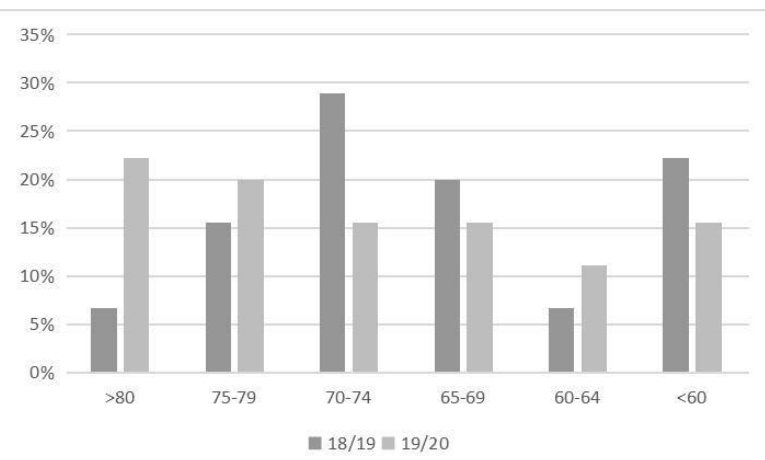

Figure 1 Changes in the Midtest Value of Environmental Epidemiology Course

Figure 1 above shows the difference in the midtest scores obtained in the Environmental Epidemiology course. The difference between the two academic years is the TSTS and Co-op Co-op learning model methods. Lie [8] conveyed that TSTS and Co-op Co-op learning is a learning system that provides opportunities for students to work together with their friends in structured tasks. This system is like mutual assistance learning, which is an alternative that can prevent aggressiveness in the competency system and competition in the individual order without sacrificing cognitive aspects. If the lecturer's learning model is not following students' goals and abilities, the students will fail in learning. Students must be accustomed to being responsible for their education. Learning is not receiving information/knowledge. Learning is a process of building culture. Experience must be extracted, not by the teacher. If students explore knowledge, and the lecturer facilitates students' learning activities, learning will be more meaningful. The results of further observations indicate that students whose grades

have not reached 60 have a background of poor learning achievement. Therefore, the lecturer must pay more attention and give maximum attention to the student concerned. In this case, the lecturer tries to provide an independent assignment with some literature reading $[2,9,10]$.

Based on the mid-test results given to the class that implements the cooperative learning model TSTS and Coop Co-op and in the previous school year class with conventional methods, it can be seen that the difference in the results of students statistically using different tests. Before the difference test was carried out, the analysis requirements test was carried out in the form of a normality test and a homogeneity test. The normality test results using the Kolmogorov-Smirnov show that the expected class normality test results obtained a significance value of 0.384 , greater $\alpha 0.05(0.384>0.05)$. Thus it can be concluded that the test results show typical results, namely the distribution of the midtest values has spread usually. Using Lavene's Test on the standard class mid-test value, the homogeneity test results obtained a significance value of 0.066 higher than $\alpha 0.05(0.066>0.05)$. Thus it can be concluded that the test results show homogeneity; that is, the sample group comes from a population with variance different. After the normality test and homogeneity test have been fulfilled, a separate analysis is performed using the two-difference t-test.

From the results of the t-test between the midtest values of students in the TSTS and Co-op Co-op classes and the conventional class, it is known that the t-count on the students' midtest value is 2.94 , more significant than the ttable of $2.026(2.94>2.026)$. This value shows that the results of the midtest students of TSTS and Co-op Co- op increased significantly compared to the conventional class. The results of the t-test above indicate that Ho is rejected and $\mathrm{Ha}$ is accepted, that is, there are differences in the effectiveness of the cooperative learning model in increasing the mid-test value of students in Environmental Epidemiology compared to conventional learning. So it can be concluded that the TSTS and Co-op Co-op learning model is more effective for improving student learning outcomes compared to traditional methods.

Besides, students feel positive results with the application of learning with the TSTS and Co-op Co-op methods. This data can be seen based on the Table 2 (results of the questionnaire given after the midtest).

Table 2. Results of Satisfaction with The Improvement of Softskills

\begin{tabular}{|c|c|c|}
\hline No. & Skills & Percentage (\%) \\
\hline 1 & $\begin{array}{l}\text { Developed ability to analyze } \\
\text { cases/problems }\end{array}$ & 年 \\
\hline 2 & Increased scientific writing skills & 83.7 \\
\hline 3 & 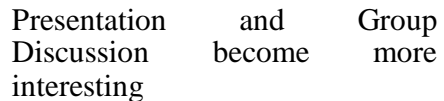 & 95 \\
\hline 4 & $\begin{array}{l}\text { Interactive Discussion makes the } \\
\text { learning process more interesting }\end{array}$ & 90 \\
\hline 5 & $\begin{array}{l}\text { Discuss and engage in problem- } \\
\text { solving }\end{array}$ & 100 \\
\hline 6 & Optimizing his/herself & 90 \\
\hline 7 & $\begin{array}{l}\text { Increasing Interest in Active } \\
\text { Learning, both individually and } \\
\text { in groups }\end{array}$ & 95 \\
\hline 8 & $\begin{array}{l}\text { More enthusiastic and understand } \\
\text { more about the material given } \\
\text { because they have prepared from } \\
\text { home }\end{array}$ & 84.3 \\
\hline 9 & $\begin{array}{l}\text { Learn to speak in public and be } \\
\text { responsible }\end{array}$ & 76.3 \\
\hline
\end{tabular}


One of the constraints occurred in the implementation of TSTS dan Co-op Co-op learning model was that students are not accustomed to giving questions, and arguments when discussing in front of the classroom and preferably the teacher needs to verify the chances of each group in preparing items for the group in front of the class.

Even so, this study was constrained by its observations until the midterm assessment only. After that, the COVID-19 pandemic outbreak occurred at the study location, so that learning turned into online media use. This condition is a limitation on the studies that have been conducted. The following is documentation of implementation in face-to-face activities in class.

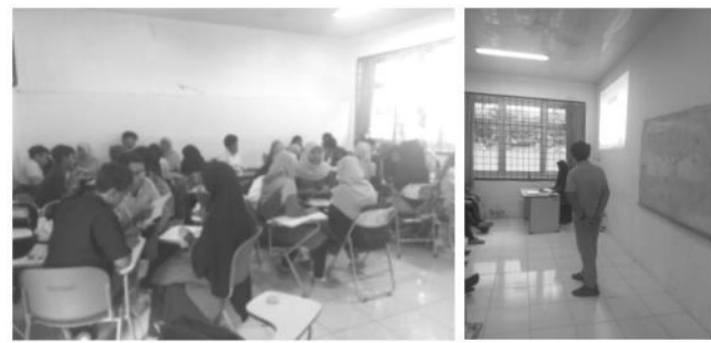

Figure 2 TSTS and Co-op Co-op in The Classroom

\section{CONCLUSION}

From the application of the SCL method in the Environmental Epidemiology subject in the 2019/2020 academic year, it can be concluded that the implementation of SCL with the Two Stay Two Stray and Co-op Co-op methods has a positive effect on the development of student abilities. Both hard skills and soft skills. This conclusion can be seen from the significant increase in learning outcomes during the UTS evaluation with a probability value of less than 0.05 .

\section{AUTHORS' CONTRIBUTIONS}

Taufiq Ihsan: Conceptualized the study, prepared protocols and conducted data collection, literature search, involved in data analysis, drafting and finalization of the manuscript.

Tivany Edwin: Data collection, analysis the data and guided in the study design

\section{ACKNOWLEDGMENT}

This work was supported by Institute of Educational Development and Quality Assurance (LP3M)
Universitas Andalas under SK Rektor Universitas Andalas No. 100/XIII/R/KPT/2020

\section{REFERENCES}

[1] A. Suprijono, Cooperative Learning Teori dan Aplikasi PAIKEM, Pustaka Pelajar, 2009.

[2] D. Sulisworo, F. Suryani, The Effect of Cooperative Learning, Motivation and Information Technology Literacy to Achievement, International Journal of Learning \& Development, vol. 4(2), 2014, pp. 5864. DOI: $10.5296 /$ ijld.v4i2.4908.

[3] R. E. Slavin, N. Yusron, Cooperative Learning Teori, Riset, dan Praktik, Nusa Media, 2005.

[4] S. Kagan, M. Kagan, Kagan Cooperative Learning, Kagan Publishing, 2009.

[5] I. W. Wijayati. The Effectiveness Of Two Stay Two Stray Technique In Teaching Reading Through Procedure Text For Eleventh Grade Students Of SMK Maospati In The Schooling Year Of 2015/2016. Jurnal Ilmiah Pendidikan, 2016.

[6] S. Arikunto, S. Suhardjono, Penelitian Tindakan Kelas, PT Bumi Aksara, 2015.

[7] R.P. Pelton, Action Research for Teacher Candidates, United States of America, 2010

[8] A. Lie, Cooperative Learning Mempraktek an Cooperative Learning di Ruang-Ruang Kelas, Grasindo, 2007.

[9] G. J. Hwang, P. Y. Yin, C. W. Hwang, C. C. Tsai, An Enhanced Genetic Approach to Composing Cooperative Learning Groups for Multiple Grouping Criteria, Educational Technology \& Society, vol. 11(1), 2008, pp. 148-167

[10] A. Saputra, Use Of Two Stay Two Stray Strategy in Teaching Reading. English Education Journal, vol. 7(2), 2016, pp. 219-232 